\title{
Studies on the Preparation and Shelf-Life of Soursop, Tamarind, and Blended Soursop-Tamarind Soft Drinks'
}

\author{
J. R. Benero, A. L. Collazo de Rivera, and L. M. I. de George ${ }^{2}$ \\ INTRODUCTION
}

Individual soursop (Anona muricata L.) and tamarind (Tamarindus indica L.) trees may be found scattered throughout the Island, although they grow wild mostly in the mountainous regions close to Salinas, Guayama, and Yauco. The fruit is picked when ripe and sold locally in the fresh fruit market. In recent years, however, these fruits are more frequently processed commercially in the manufacture of nectars, pulps, and syrups.

Because of their rich flavor and aroma, it was thought possible to expand their use commercially by developing a method for preparing good quality soft drinks.

This paper presents information on the formulation, preparation and canning of soursop, tamarind, and tamarind-soursop drinks, and their evaluation throughout a shelf-life study.

Benero et al. described the procedure for the extraction of soursop and tamarind pulps $(2,3)$; Sanchez et al. (7) reported on the preparation of a soursop nectar; and Baragaño de Mosqueda (1) on a process for the production of a clarified tamarind juice.

A comprehensive process for the production of soft and carbonated drinks in general is described by Brownie (4) and Jacobs (5), respectively.

\section{MATERIALS AND METHODS}

The fruit used in this study was purchased at the local market. The pulp utilized as a base for the preparation of the drinks was extracted following the procedure described by Benero et al. The drinks were prepared by dispersing the fruit pulp in water at the desired concentration and adjusting the soluble-solids content with sugar. Soursop drinks were prepared at fruit-pulp concentrations of 10-, 11-, 12-, 13-, 14-, and 15-percent and soluble solids of $15^{\circ}$ Brix; tamarind drinks at 9-, 10-, 11-, and 12-percent concentrations and a $21.5^{\circ}$ Brix soluble-solids level; and soursop-tamarind blended drinks at blended-pulp levels of 10-, 11-, 12-, 13-, and 14-percent

1 Manuscript submitted to Editorial Board June 14, 1973.

2 Associate Chemist, Assistant Chemist, and Assistant Food Technologist, respectively, Food Technology Laboratory, Agricultural Experiment Station, Mayagüez Campus, University of Puerto Rico, Rio Piedras, P.R. 
and two different soluble-solids concentrations: $15^{\circ}$ and $17^{\circ}$ Brix. The fruit-pulp concentration was increased by adding tamarind pulp to the 6:4 soursop-tamarind ratio used for the 10-percent drink. Following are the soursop:tamarind ratios for the various drinks: 10-percent pulp content, 6:4; 11-percent, 6:5; 12-percent, 6:6; 13-percent, 6:7; and 14-percent, $6: 8$.

The drinks were pasteurized in a short-time pasteurizer at $185^{\circ}$ to $190^{\circ}$ $F$, canned in 71/2-ounce plain tin containers, sealed, water-cooled, and air-dried. The cans were then stored at $85^{\circ} \mathrm{F}$ to conduct shelf-life studies.

Drink quality was checked periodically by a trained tasting panel consisting of 10 to 15 members. Samples were evaluated by a ranking test to determine preference and rated by using a $+2,-2$ hedonic scale in which +2 equals "very acceptable" and -2 , "not acceptable." The results were

TABLE 1.-Chemical composition of freshly prepared soursop drink

\begin{tabular}{ccccc}
\hline Pulp content & Soluble solids & Titrable acidity & Total sugars & pH \\
\hline Percent & ${ }^{\circ}$ Brix & Percent cilric acid & Percent & \\
10 & 15.4 & 0.08 & 14.79 & 3.81 \\
11 & 16.2 & .09 & 15.83 & 3.78 \\
12 & 14.8 & .11 & 14.24 & 3.75 \\
13 & 15.1 & .11 & 14.89 & 3.72 \\
14 & 15.3 & .13 & 14.98 & 3.75 \\
15 & 15.4 & .14 & 15.21 & 3.70 \\
\hline
\end{tabular}

analyzed by the method described by Kramer and Ditman (6). Blended drinks were compared by the paired test method to determine preference between the $15^{\circ}$ - and the $17^{\circ}$ Brix soluble-solids levels.

\section{RESULTS AND DISCUSSION}

\section{SOURSOP DRINK}

Six lots of soursop drinks were prepared, having pulp concentrations which ranged from 10- to 15-percent, and soluble solids, titrable acidity, and total sugars contents as shown in table 1 . When evaluated by the ranking test, the panel rejected the 10-percent sample in contrast with those of 11-, 12-, 13-, 14-, and 15-percent; but no significant difference could be established between them when rated individually by the +2 , -2 hedonic scale.

During the shelf-life study of soursop drinks, the cans containing the 10- and 11-percent pulp concentrations swelled after 341 days and their evaluation was discontinued. Drinks containing 12- to 15-percent soursop 
pulp concentrations remained acceptable, however, for over 1 year. The results are shown in table 2.

\section{TAMARIND DRINK}

No significant difference was found between tamarind drinks containing 9-, 10-, 11-, and 12-percent fruit, when rated either separately by using the $+2,-2$ hedonic scale or evaluated by a ranking test. The chemical composition of the freshly prepared drinks is given in table 3.

TABLE 2.-Average ratings ${ }^{1}$ of soursop drinks during shelf life study

\begin{tabular}{rcccccc}
\hline \multirow{2}{*}{ Storage. } & \multicolumn{7}{c}{ Pulp content (percent) } \\
\cline { 2 - 7 } & 10 & 11 & 12 & 13 & 14 & 15 \\
\hline Days & & & & & & \\
54 & +0.9 & +1.05 & +0.6 & +0.9 & +1.0 & +1.4 \\
145 & +1.3 & +1.1 & +1.2 & +1.4 & +1.2 & +1.2 \\
235 & +.5 & +1.0 & +.9 & +.4 & +.5 & +.9 \\
286 & +.7 & +.9 & +.8 & +.5 & +1.2 & +1.2 \\
341 & - & - & +.8 & +.8 & +.8 & +.8 \\
397 & - & - & +.9 & +1.2 & +.7 & +.9 \\
\hline
\end{tabular}

1 Using the $+2,-2$ hedonic scale in which +2 means "very acceptable" and -2 "not acceptable."

TABLE 3.-Chemical composition of freshly prepared tamarind drinks

\begin{tabular}{ccccc}
\hline Pulp content & Soluble solids & Titrable acidity & Total sugars & pII \\
\hline Perce" & ${ }^{\circ}$ Brit & Percent lartaric acid & Percent & \\
9 & 21.4 & 0.35 & 20.86 & 2.93 \\
10 & 20.7 & .42 & 20.53 & 2.98 \\
11 & 20.6 & .41 & 19.85 & 2.92 \\
12 & 20.5 & .44 & 19.29 & 2.80 \\
\hline
\end{tabular}

Table 4 shows the average ratings received by the samples during the shelf-life study. The drinks remained acceptable for about 1 year.

\section{SOURSOP-TAMARIND BLENDED DRINKS}

The blended soursop-tamarind drinks were evaluated and no significant preference could be established between the different pulp levels or solublesolids concentrations. Nonetheless, when the samples were compared by the paired test, there was a tendency to prefer the $17^{\circ}$ Brix over the $15^{\circ}$ Brix drink. The chemical composition of the blended drinks appears on table 5.

The drinks remained acceptable for about 10 months, as shown in table 6. 
TABLE 4.-Average ratings of tamarind drinks during shelf-life study

\begin{tabular}{rrrrc}
\hline \multirow{2}{*}{ Storage } & \multicolumn{4}{c}{ Pulp content (percent) } \\
\cline { 2 - 5 } & 9 & 10 & 11 & 12 \\
\hline 7 & +1.0 & +1.1 & +1.1 & +1.25 \\
52 & +1.2 & +1.0 & +1.3 & +1.3 \\
120 & +.8 & +.7 & +1.0 & +1.0 \\
182 & +1.0 & +1.0 & +1.0 & +.8 \\
230 & +1.1 & +.8 & +.9 & +.8 \\
288 & +1.0 & +1.0 & +1.3 & +.9 \\
432 & +.7 & +.7 & +.6 & +.4 \\
\hline
\end{tabular}

TABLE 5.-Chemical composition of freshly prepared soursop-lamarind blended drinks

\begin{tabular}{ccccc}
\hline $\begin{array}{c}\text { Pulp content } \\
\text { (percent) }\end{array}$ & $\begin{array}{c}\text { Soluble solids } \\
\text { ('Brix) }\end{array}$ & $\begin{array}{c}\text { Titrable acidity } \\
\text { (percent citric acid) }\end{array}$ & $\begin{array}{c}\text { Total sugars } \\
\text { (percent) }\end{array}$ & pH \\
\hline & & $15^{\circ}$ Brix & & \\
\hline 10 & 15.0 & 0.22 & 15.07 & 3.66 \\
11 & 15.4 & .22 & 15.38 & 3.62 \\
12 & 15.1 & .24 & 15.03 & 3.60 \\
13 & 15.1 & .27 & 14.99 & 3.57 \\
14 & 15.3 & .30 & 15.22 & 3.53 \\
\hline & & $17^{\circ}$ Brix & & \\
10 & 17.5 & 0.17 & 16.54 & 3.30 \\
11 & 17.9 & .21 & 17.8 & 3.19 \\
13 & 17.7 & .23 & 17.49 & 3.16 \\
14 & 18.0 & .27 & 17.07 & 3.35 \\
& 18.0 & .29 & 17.73 & 3.08 \\
\hline
\end{tabular}

\section{SUMMARY}

Soursop, tamarind, and blended tamarind-soursop soft drinks were prepared by dispersing the desired amount of fruit pulp in water and adjusting the soluble-solids concentration to the corresponding Brix level. The drinks then were pasteurized in a short-time pasteurizer at $185^{\circ} \mathrm{F}$, canned in 71/2-ounce plain tin containers, cooled under water, air-dried, and finally stored at $85^{\circ} \mathrm{F}$.

For soursop drinks, levels of 10- to 15-percent fruit-pulp content were dried at a $15^{\circ}$ Brix soluble-solids concentration; and for tamarind, levels of 9- to 12-percent pulp with the soluble solids adjusted at $21.5^{\circ}$ Brix. In the case of blended drinks, the fruit pulp contents were varied from 10to 14-percent by increasing the ratio of tamarind pulp to soursop. Two soluble-solids concentrations were studied: $15^{\circ}$ and $17^{\circ}$ Brix. 
The sensory evaluation of the drinks at different pulp concentrations, which were performed during the shelf-life studies, revealed no significant differences among the samples tested, although a tendency to prefer the sweeter one ( $17^{\circ}$ Brix) was observed in the case of the blended drink.

Soursop drinks with 12- to 15-percent pulp content remained acceptable for over 1 year and tamarind drinks throughout the whole year of the shelf-life study. Blended drinks were found acceptable for over 10 months.

TABLE 6.-Average ratings ${ }^{1}$ soursop-tamarind blended drinks during shelf-life study

\begin{tabular}{|c|c|c|c|c|c|c|}
\hline \multirow{2}{*}{$\begin{array}{l}\text { Storage } \\
\text { (dayg) }\end{array}$} & \multicolumn{6}{|c|}{ Pulp-content percent and soursop: tamarind ratios } \\
\hline & $10(6: 4)$ & $11(6: 5)$ & $12(6: 6)$ & $13(6: 7)$ & & $14(6: 8)$ \\
\hline & \multicolumn{3}{|c|}{$16^{\circ}$ Brix } & \multicolumn{3}{|c|}{ 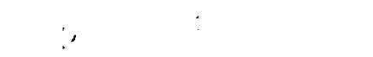 } \\
\hline 9 & 0.6 & 0.8 & 0.7 & 0.4 & & 0.5 \\
\hline 85 & .8 & .8 & 1.0 & 1.0 & & 1.0 \\
\hline 135 & .5 & 1.1 & .7 & 1.1 & & .9 \\
\hline 195 & 1.0 & .5 & .8 & - & & - \\
\hline 250 & 1.0 & .9 & 1.0 & .8 & . & .8 \\
\hline 323 & .7 & .5 & .8 & .1 & & .2 \\
\hline 373 & .4 & .3 & .3 & .7 & & .3 \\
\hline \multicolumn{7}{|c|}{$17^{\circ}$ Brix } \\
\hline 48 & 0.2 & 0.5 & 0.2 & 0.9 & & 0.2 \\
\hline 83 & .6 & .6 & .7 & 1.1 & & 1.1 \\
\hline 147 & 1.0 & .8 & 1.0 & .7 & . & .6 \\
\hline 255 & .8 & .8 & 1.0 & .6 & $\because$ & .8 \\
\hline 331 & .8 & 1.0 & 1.0 & .8 & & .9 \\
\hline 379 & .6 & .7 & 1.0 & .5 & & .5 \\
\hline
\end{tabular}

1 Values represent the average score of 10 to 13 panelists, using a $+2,-2$ hedonic scale.

\section{RESUMEN}

Se prepararon refrescos de guanábana, de tamarindo y de una combibinación de ambas frutas, mediante la dispersión de la pulpa en agua, ajustando el nivel de la acidez y de los sólidos solubles y pasterizándolos luego en un pasterizador de acción rápida a $185^{\circ} \mathrm{F}$. Después se envasaron los refrescos en latas estañadas, se enfriaron con agua, se secaron y se almacenaron a $85^{\circ} \mathrm{F}$.

En el caso de los refrescos de guanábana, se estudiaron niveles de pulpa de 10 a 15 por ciento y un contenido de sólidos solubles de $15^{\circ} \mathrm{Brix}$, y en el de los refrescos de tamarindo, niveles de pulpa de 9 a 12 por ciento, con los sólidos solubles ajustados a $21.5^{\circ}$ Brix. En el caso de la combinación de 
guanábana con tamarindo el contenido de pulpa se hizo variar de 10 a 14 por ciento, aumentando proporcionalmente la cantidad de tamarindo respecto a la de guanábana. Se estudiaron dos niveles distintos de sólidos solubles: $15^{\circ}$ y $17^{\circ}$ Brix.

Los catadores no encontraron diferencia significativa alguna entre los diversos niveles de pulpa en los refrescos que se probaron, pero se not6 una tendencia a preferir el refresco más dulce, con $17^{\circ}$ Brix, en la combinación de guanábana con tamarindo.

La calidad de los refrescos se mantuvo aceptable por períodos de alrededor de 1 año.

\section{LITERATURE CITED}

1. Baragaño de Mosqueda, M., Technology of Clarified Tamarind Juice, Sp. Soc. Cieve Natur., La Salle Memo. 26 (73): 62-8, 1966.

2. Benero, J. R., Rodriguez, A. J., and Collazo de Rivera, A., A mechanical method for the extraction of tamarind pulp, J. Agr. Univ. P.R. 56 (2): 185-6, 1972.

3. - - - Román de Sandoval, A., Soursop pulp extraction procedure, J. Agr. Univ. P.R. 55 (4) : 518-9, 1971.

4. Brownie, C. W., The Chemistry and Technology of Food and Food Products, Vol. II, Chap. XIV, Interscience Publishing Inc., New York, N.Y., pp. 435-6, 1944.

5. Jacobs, M. B., Manufacture and Analysis of Carbonated Beverages, Chemical Publishing Co., Inc., 212 Fifth Ave., New York, N.Y., 1959.

6. Kramer, A., and Ditman, L. P., A Simplified Variable Taste Panel Method for Detecting Flavor Changes in Vegetables Treated with Pesticides, Food Tech. 10: 155-9, 1956.

7. Sánchez-Nieva, F., Igaravídez, L., and Ramos López, B., The Preparation of Soursop Nectar, Univ. P.R. Agr. Exp. Sta. Tech. Paper 11, Rio Piedras, P.R., May 1953. 